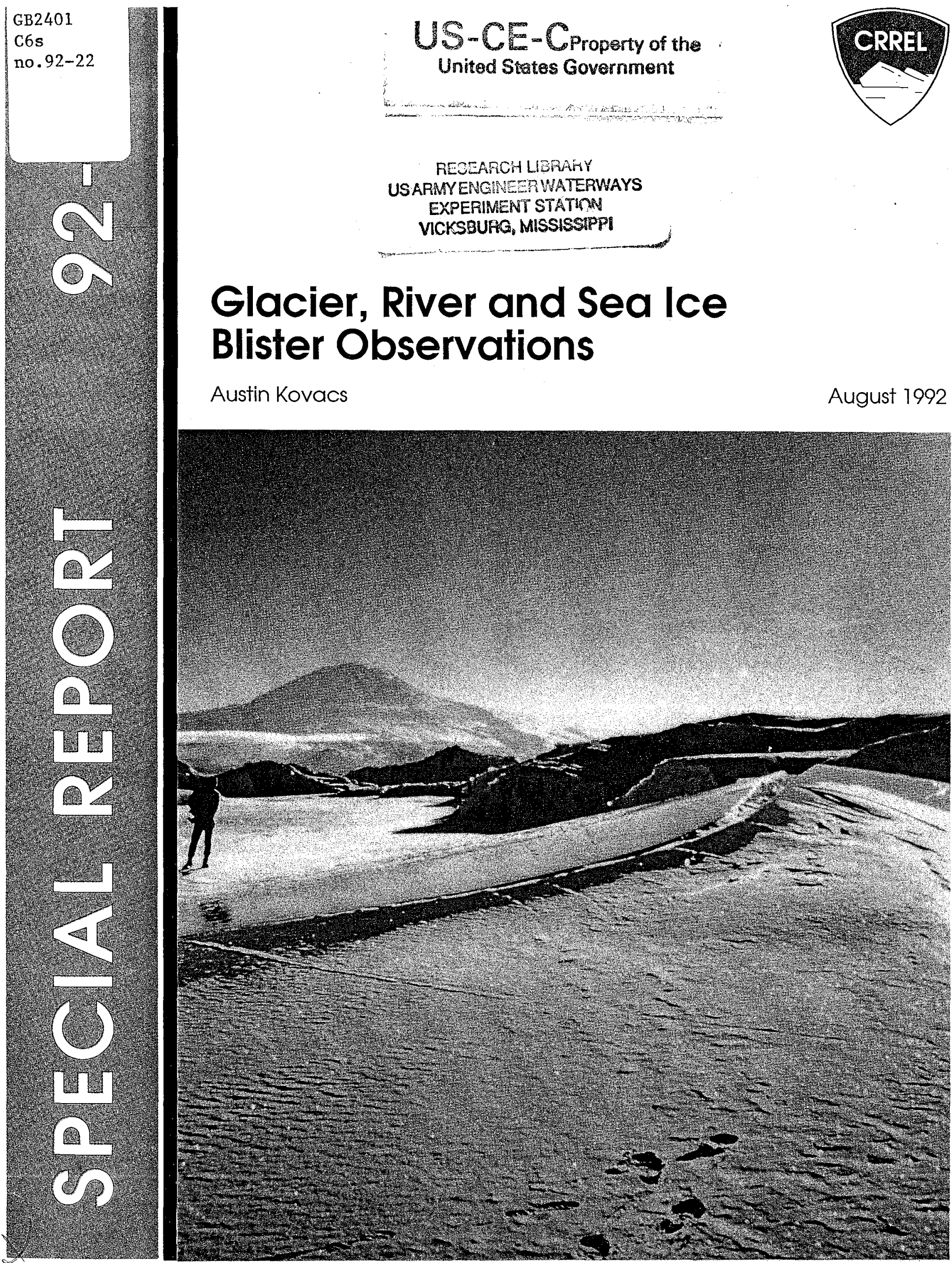


Abstract

Ice blister observations made by the author in Greenland, Alaska and Antarctica are discussed. Ice blisters up to $3 \mathrm{~m}$ high and tens of meters long were observed on rivers and glaciers as well as on a subsurface glacial pool. Ice blisters observed by other investigators are also discussed, as is ice blister morphology (solid, hollow or water-filled), the processes associated with their formation and their potential as a resource for potable water.

Cover: Ice blister on refrozen melt "river," Koettlitz Glacier Ice Tongue, Antarctica. Mt. Erebus rises majestically some $100 \mathrm{~km}$ in the distance. Note the wind-polished ice on the left flank of the blister and the typical cleavage crack, which is broadest at the apex of the ice blister.

For conversion of $\mathrm{SI}$ metric units to U.S./British customary units of measurement consult ASTM Standard E380, Metric Practice Guide, published by the American 


\section{Special Report 92-22}

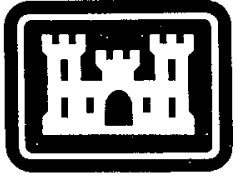

\section{U.S. Army Corps of Engineers}

Cold Regions Research \& Engineering Laboratory

\section{Glacier, River and Sea Ice Blister Observations}

Austin Kovacs 


\section{PREFACE}

This report was prepared by Austin Kovacs, Research Civil Engineer, Applied Research Branch, Experimental Engineering Division, U.S. Army Cold Regions Research and Engineering Laboratory.

The author acknowledges the background information provided by Dr. William Harrison of the Geophysical Institute, University of Alaska, on his Greenland ice blister observations, Frederick E. Crory of CRREL on his Alaska ice blister observations and Giles McDonald of Anchorage, Alaska, on the exploded icing reported in Sloan et al. (1976). He also acknowledges the review of this report by Frederick Crory and Kevin L. Carey of CRREL.

The contents of this report are not to be used for advertising or promotional purposes. Citation of brand names does not constitute an official endorsement or approval of the use of such commercial products. 


\section{CONTENTS}

\begin{tabular}{|c|}
\hline Preface \\
\hline Introduction \\
\hline Terminology \\
\hline Ice blister observation \\
\hline Antarctic ice blisters \\
\hline Alaskan ice blisters \\
\hline Greenland ice blisters \\
\hline Discussion \\
\hline iterature cited \\
\hline 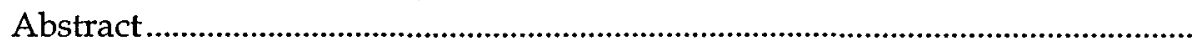 \\
\hline
\end{tabular}

\section{ILLUSTRATIONS}

Figure

1. Hollow ice blister observed on the Jakobshavns Isbrae, Greenland ........

2. Solid ice blister observed on the Jakobshavns Isbrae, Greenland ............ . 2

3. Idealized frost mound .............................................................................

4. River of summer meltwater on the Koettlitz Glacier Ice Tongue, McMurdo Sound, Antarctica ...................................................................

5. One-meter-high ice blister in a refrozen melt river on the Koettlitz Glacier Ice Tongue

6. Ice blister in a melt pool on the Koettlitz Glacier Ice Tongue surrounded by summer meltwater.

7. Gravel in a melt river on the Koettlitz Glacier Ice Tongue

8. Conical 3-m-high ice blister in a refrozen melt river on the Koettlitz Glacier Ice Tongue

9. Cross section of a sinuous ice blister on the Katakluruk River near its discharge into Camden Bay, Beaufort Sea coast, Alaska ................. 6

10. Alaska North Slope river ice blister shapes .......................................

11. Icing remnant on the Firth River, Yukon Territory, Canada, in mid-September 1981

12. Trench cut into an ice blister alongside a cavity containing a boulder and some fibrous organic material.

13. Three-meter-high ice blister in the drainage area beside the runway at Umiat, Alaska

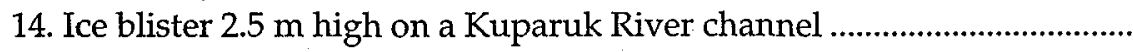

16. Canadian Center for Remote Sensing C-band SAR image taken from an altitude of about $6.1 \mathrm{~km}$, showing a section of the Kuparuk River system and some of the surrounding oil field development ...............

17. Cross section of an ice well at Camp Century, Greenland. 


\title{
Glacier, River and Sea Ice Blister Observations
}

\author{
AUSTIN KOVACS
}

\section{INTRODUCTION}

A paper recently appeared in the Journal of Glaciology (Echelmeyer et al. 1991) in which reference was made to ice blister formations that they believed had not previously been reported in the literature. These ice blisters, found on the Jakobshavn Isbrae ice field in Greenland, varied from 3 to $8 \mathrm{~m}$ in height and 7 to $20 \mathrm{~m}$ in length. Two types were noted: hollow (Fig. 1) and solid (Fig. 2).
All blisters were found in the ablation zone where summer surface melt forms pools in glacial ice depressions, crevasses or surface streams. In this report other ice blister observations made in Antarctica, Greenland and Alaska are presented. These observations include river and surface and subsurface glacial ice blister formations up to $4 \mathrm{~m}$ high and tens of meters long, both solid and water-filled. The process related to ice blister formation is also described.

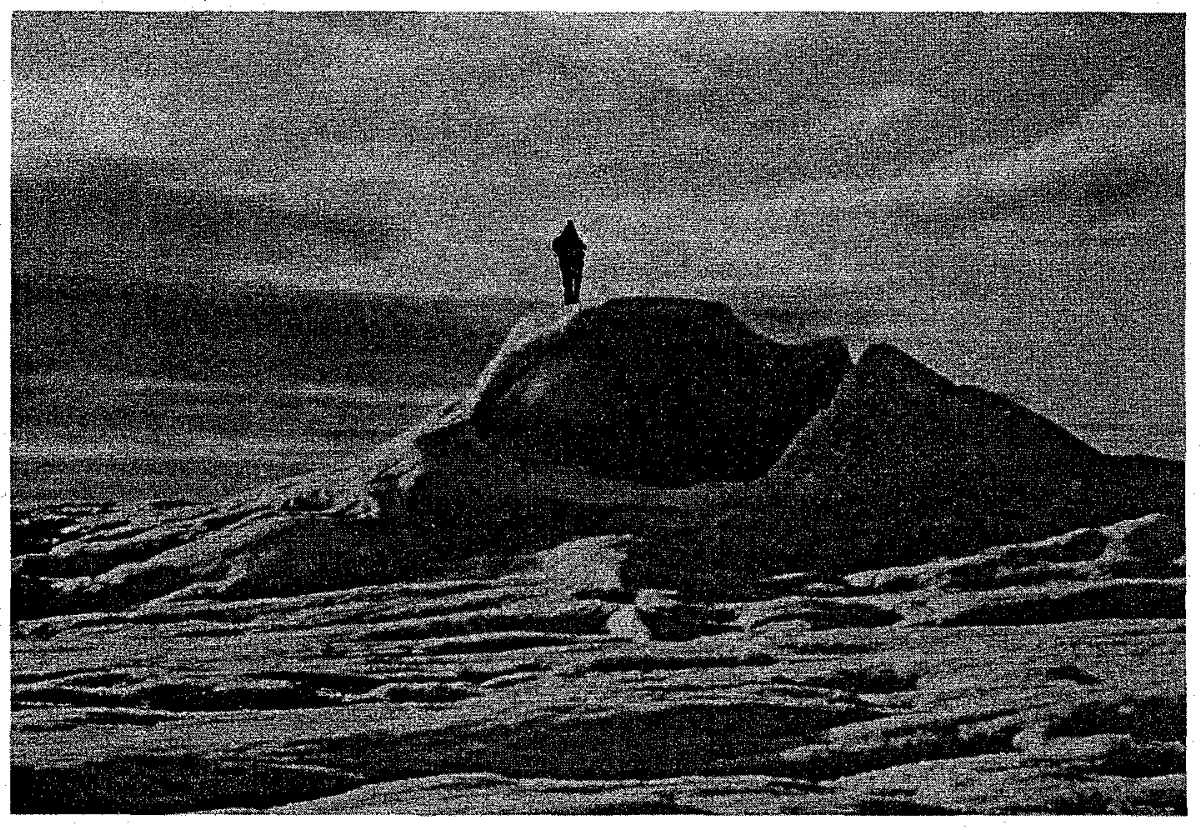

Figure 1. Hollow ice blister observed on the Jakobshavns Isbrae, Greenland. The person in the photo is for scale; the figure was transferred from $\mathrm{another} \mathrm{photo} \mathrm{of} \mathrm{the} \mathrm{same} \mathrm{scale.} \mathrm{(Photo}$ courtesy of W.D. Harrison and K. Echelmeyer, Geophysical Institute, University of Alaska.) 


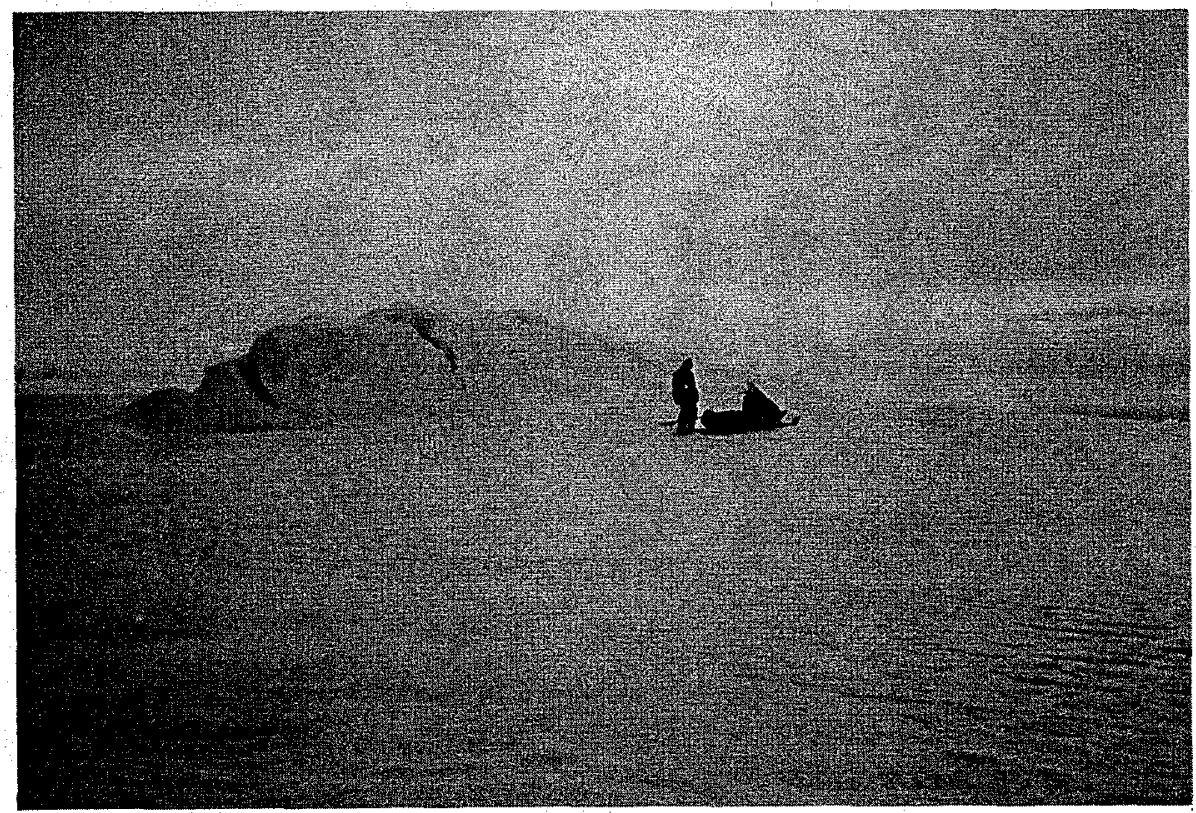

Figure 2. Solid ice blister observed on the Jakobshavns Isbrae, Greenland. (Photo courtesy of W.D. Harrison and K. Echelmeyer, Geophysical Institute, University of Alaska.)

\section{TERMINOLOGY}

In reviewing the literature it appeared that such terms as icing, icing mound, icing blister, fróst blister, frost mound, naled mound, hydrolaccolith and certain pingo types are all related to surface morphology associated with the freezing of upward-moving ground water. For example, Pollard (1991) stated that "the term icing blister was proposed by van Everdingen (1978) to distinguish mounds formed by the hydraulic lifting of icing layers by water under hydraulic potential. This process is analogous to frost blister formation.... In both cases hydraulic potential or hydrostatic pressure forces water" upward to the freezing front, as depicted in Figure 3. At times the hydrostatic pressure can build to such a level that the frozen canopy can no longer contain the water. When this occurs, the blister may split and allow the confined water to escape to form an icing, or the ice mound canopy may explode, throwing ice blocks considerable distances. Reports of this occurrence are given in Muller (1947), Strugov (1955), Plashchev (1956), Bogomolov and Sklyarevskaya (1969), Sloan et al. (1976), van Everdingen $(1978,1982)$ and Frederking (1979). It may be that the more explosive events occur when gas under hydrostatic pressure has accumulated between the ice and water. Gas bubbles coming up with suprapermafrost or subpermafrost water is not unusual (Liestol 1977, van Everdingen 1982).

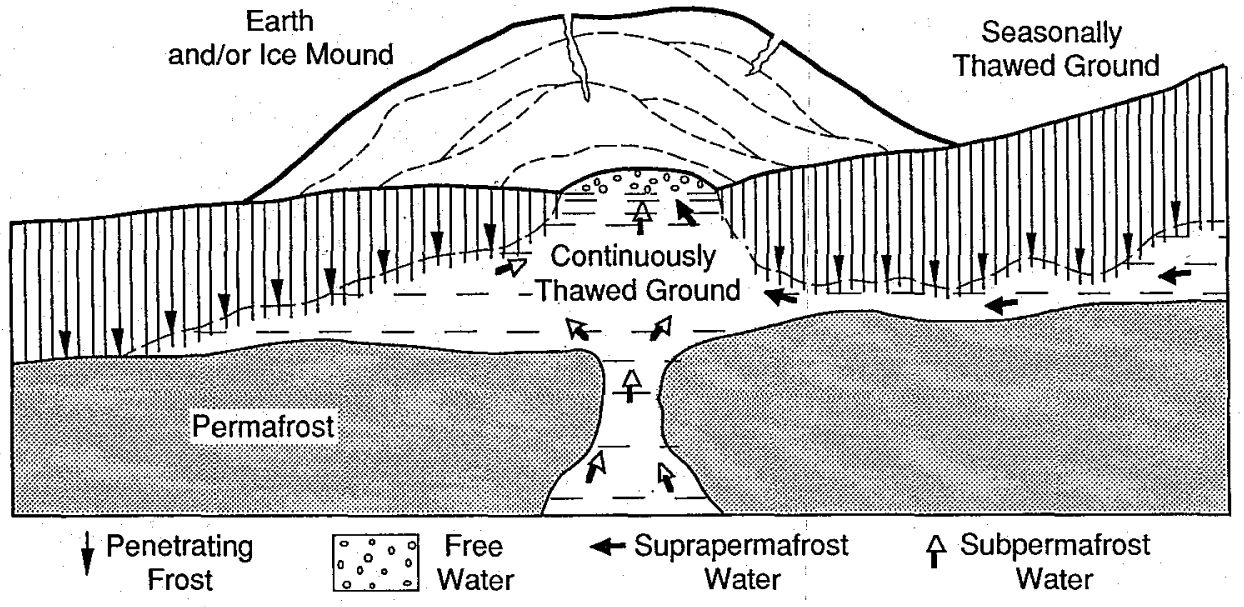

Figure 3. Idealized frost mound. The mound may consist of ice or have an earth cover underlain by ice. (After Alter 1969.) 
Seasonal frost blisters or mounds are similar to icing blisters except that the blister forms as a result of the movement of ground water upward to the bottom of the frozen active layer, where it freezes. As the process continues, crystallization forces gradually push the soil canopy and underlying ice mass upward to form a mound up to $3 \mathrm{~m}$ high (Pollard and French 1985, Pollard 1988).

Icings, also called naleds and aufeis, are formed by the freezing of successive layers of water flowing onto the surface during the winter. They generally form in rivers or in the area of springs and hillside seeps. An icing also may result if a confined body of water suddenly drains or gradually seeps out onto the surface during the freezing months. I have observed icings on the North Slope of Alaska and near the Beaufort Sea coast of the Yukon Territory of Canada that are tens of kilometers long.

As stated, the above ice features are formations associated with the upward movement of suprapermafrost or subpermafrost waterduring the freezing period. However, an ice blister or mound forms in association with a confined body of water. After an ice cover has formed, further crystallization of the confined water results in a large increase in the hydrostatic pressure and volume expansion of the ice canopy. These events combine to force the ice cover upward. The resulting ice feature may be a conical or elongated dome or a long, sinuous mound. An ice blister may be surrounded by an icing accumulation that developed before, during or after the blister formed. However, when an icing and an ice blister are both found at the same location, the ice blister is frequently referred to as an icing blister or icing mound. This can be confusing, but the confusion can be resolved, at least in the reader's mind, if a good-quality photo of the feature's morphology is provided. The fabric of the ice will certainly reveal whether the formation developed as a result of water seepage and is thus an icing mound or from crystal growth processes similar to that of lake ice and is thus an ice blister.

\section{ICE BLISTER OBSERVATIONS}

\section{Antarctic ice blisters}

In 1977, I observed ice blisters in Antarctica similar to those reported by Echelmeyer et al. (1991) in Greenland. They were located on the Koettlitz Glacier Ice Tongue. During the ablation season, significantsurface melting occurs on this glacial ice tongue. In some years the melting is so severe that "rivers" of rapidly flowing water develop and erode deep channels in the ice surface (Fig. 4). The steep ice walls of the channels were up to $6 \mathrm{~m}$ above the

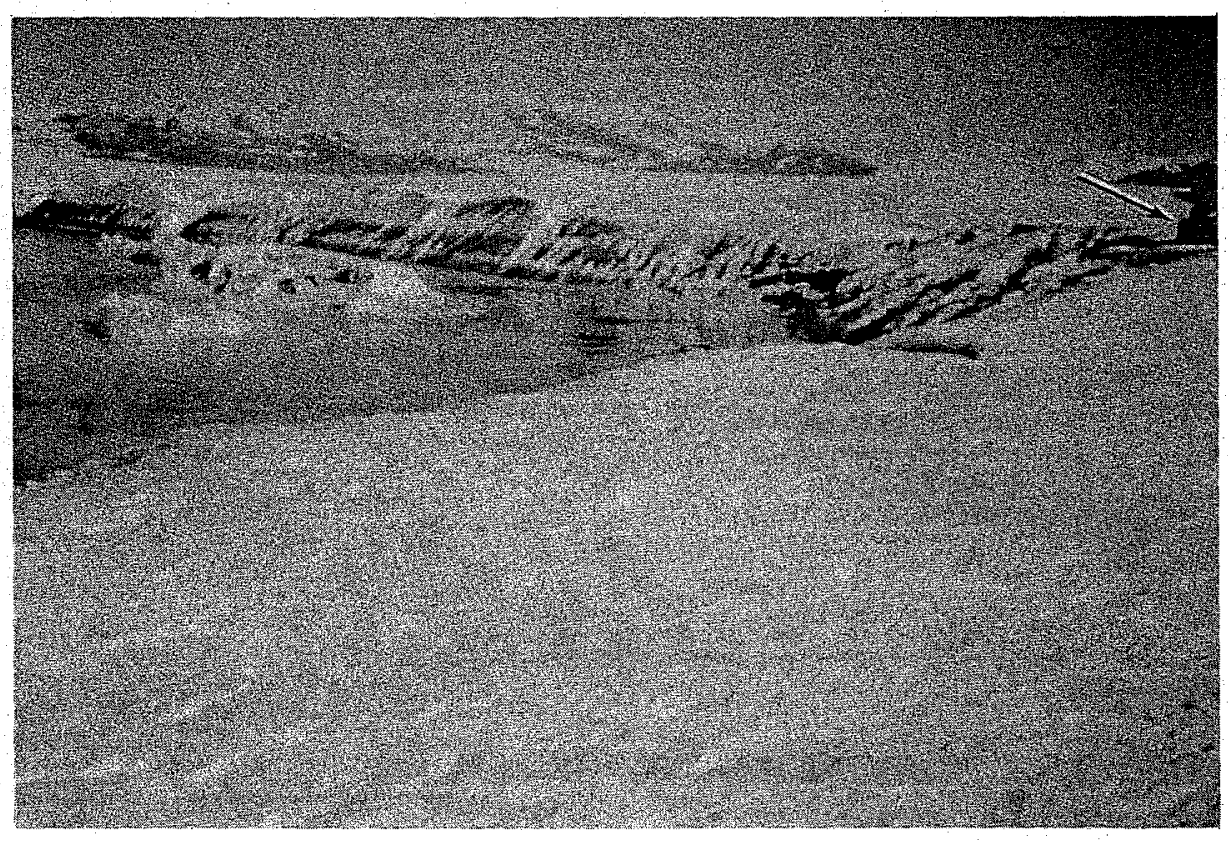

Figure 4. River of summer meltwater on the Koettlitz Glacier Ice Tongue, McMurdo Sound, Antarctica. The dark blotches in the river are granular material resting on the bottom. A small 1-m-high tracked vehicle is at the tip of the arrow. Dark bands in the river bank are related to ice fabric variations. 


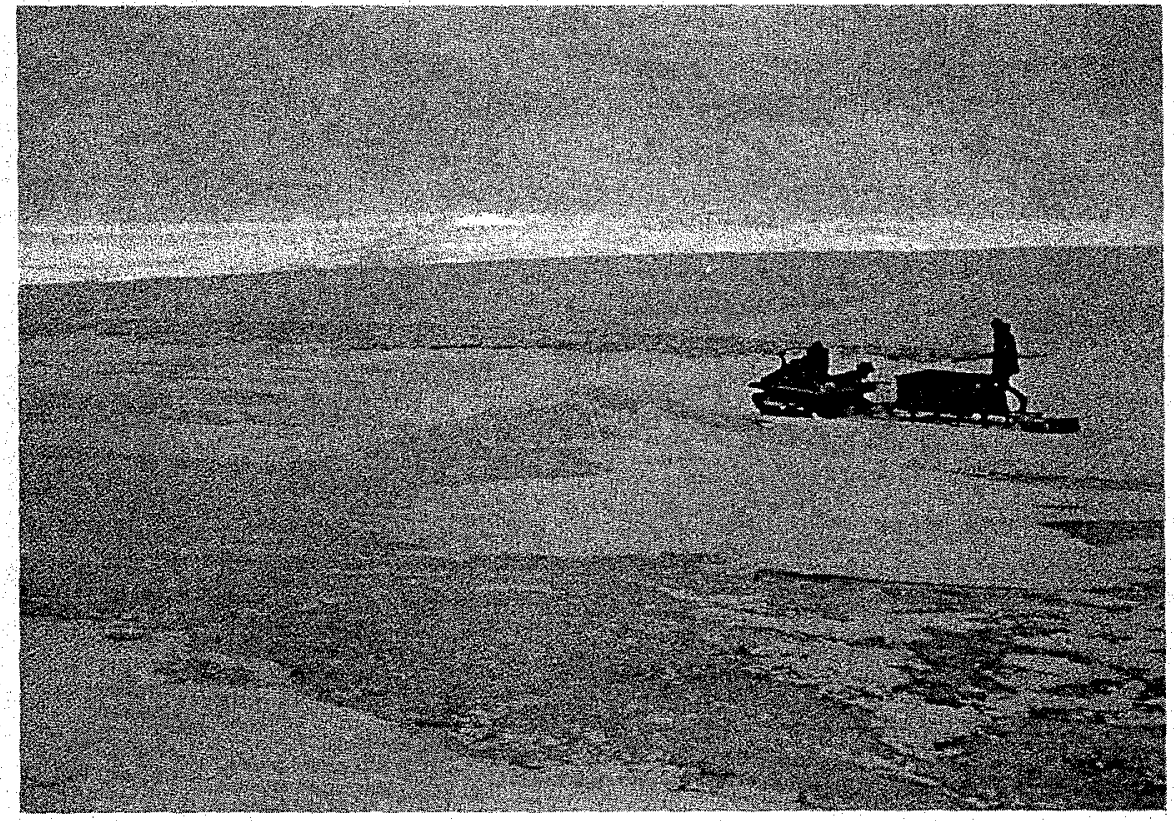

Figure 5. One-meter-high ice blister in a refrozen melt river on the Koettlitz Glacier Ice Tongue: An interesting feature of this photo is that the dark horizontal band in the river bank is saline ice that grew on the bottom of the ice tongue after the Koettlitz Glacier left the land. The ice layer above the sea ice is glacial ice that is rapidly melting away during the summers, thereby exposing underlying saline ice.

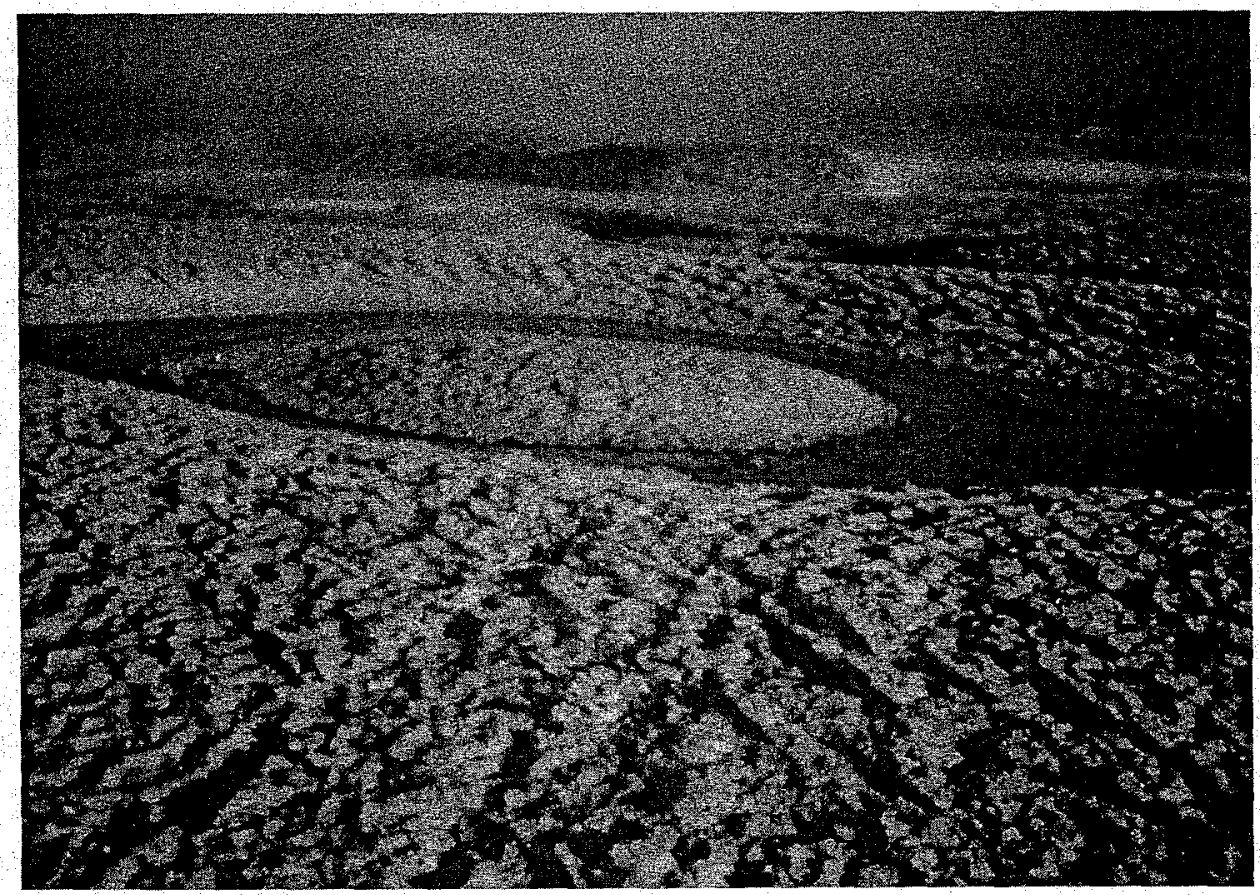

Figure 6. Ice blister in a melt pool on the Koettlitz Glacier Ice Tongue surrounded by summer meltwater. 


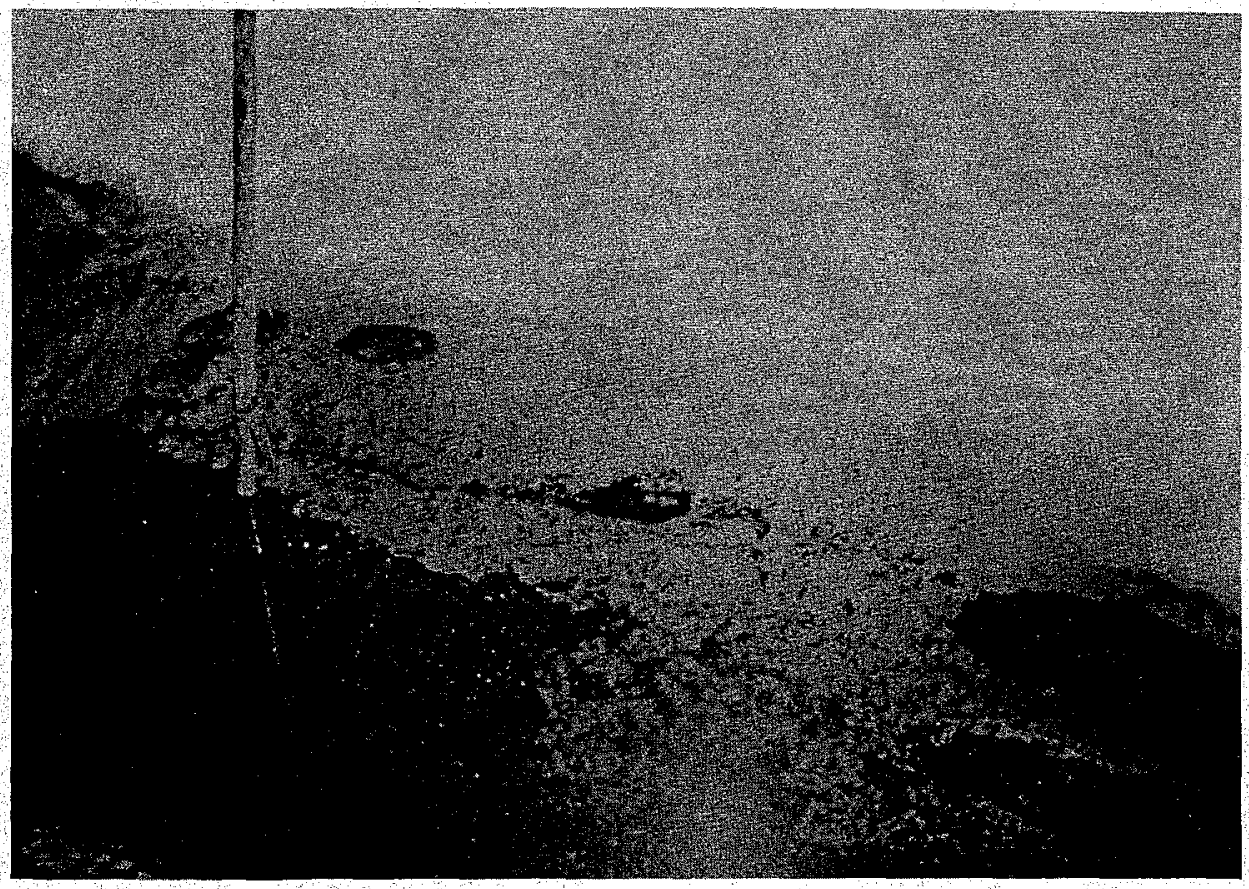

Figure 7. Gravel in a melt river on the Koettlitz Glacier Ice Tongue.

water in the areas we worked. A unique aspect of this flow is that it ran along the axis of the ice tongue back toward the area where the glacier ice became free-floating rather than toward the front of the ice tongue and into McMurdo Sound. The ice blisters observed were either cone-shaped (Fig. 5) or sinuous mounds. All were of the solid type, not filled with water or air. The ice blisters appeared to occur where deep depressions had formed in the river and stream channels or in deep melt pools (Fig. 6). Since the new ice was "transparent," one could see through it and in places observe fine sand grains and small pebbles. This material marked the boundary between the new ice and the glacier ice. Some of this granular material can be seen on the ice river bottom in Figure 4 and Figure 7.

Two ice blisters are shown in Figure 8. The prominent one, beside the person, was about $3 \mathrm{~m}$ high and conical in form. The second was about $0.5 \mathrm{~m}$ high and $5 \mathrm{~m}$ long. The apex of this feature ran along the crack in the foreground and under the feet of the photographer. The conical ice blister is seen to be highly fractured. There were six major wedges or pie-shaped pieces, which in turn were also laced with a number of surface fractures. Beside the person in Figure 8 is a block of ice about 1 $\mathrm{m}$ thick that had popped off the tip of one wedge when it was deflected upward.

Other observations of ice blisters in Antarctica were made by Van Autenboer (1962), Cailleux (1962) and Paige (1968). Van Autenboer described three ice mounds, up to $2 \mathrm{~m}$ high and $15 \mathrm{~m}$ in diameter, located near the terminus of the Gunnestadbreen Glacier. The ice feature he shows in his Figure 2, page 351, is very similar to the one shown in Figure 5 of this report. Cailleux found ice blisters up to $0.5 \mathrm{~m}$ high in several frozen lakes on Ross Island, whereas Paige observed numerous ice mounds up to $0.6 \mathrm{~m}$ high that formed over melt pool sites found throughout the bare ice ablation zone at the western part of the McMurdo Ice Shelf.

The conical ice blister shown here in Figure 8 bears a resemblance to the sketch of a unique sea ice feature described as an ice blister by Wright and Priestly (1922, page 343). They stated that "On several occasions peculiar structures were observed in sea ice which resembled in appearance nothing so much as the skin of a blister, which had broken...." Their explanation for the sea ice blisters. they observed was a sudden discharge of gas from beneath the ice sheet. This explanation certainly does not apply to the solid ice blisters observed on 


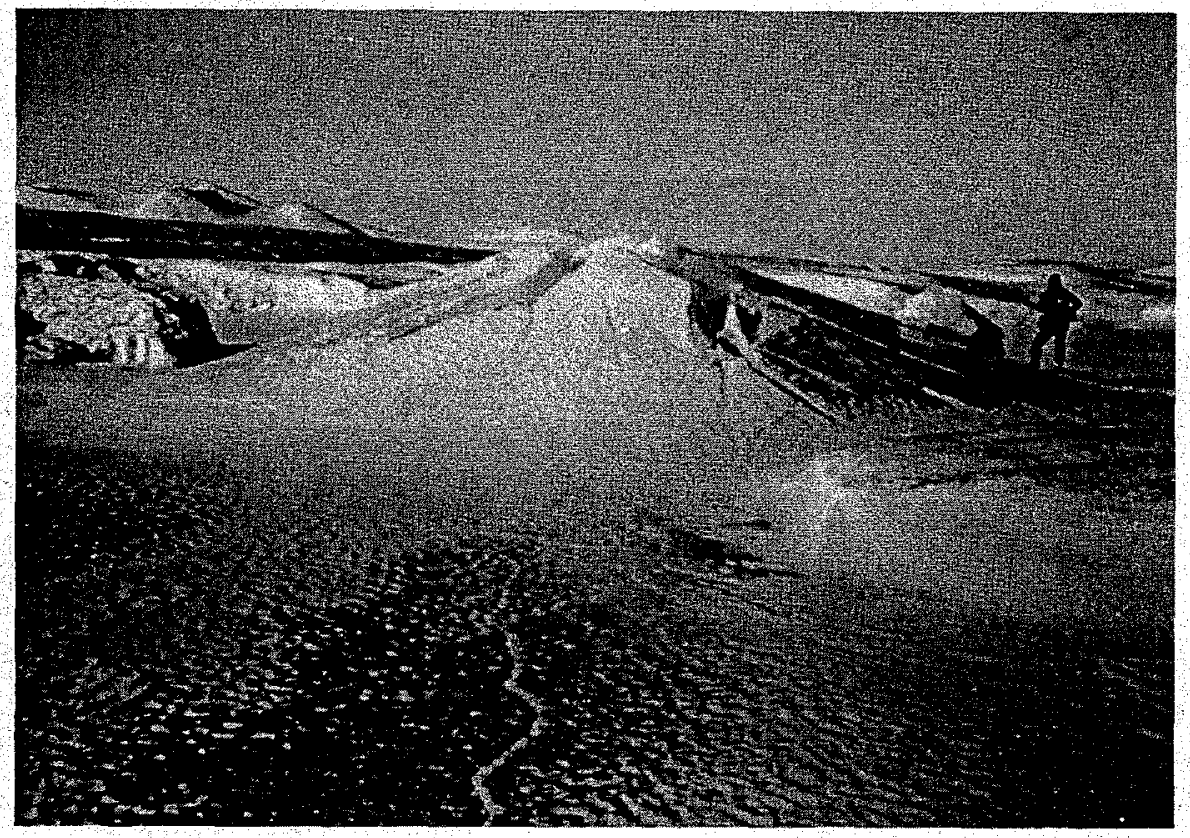

Figure 8. Conical 3-m-high ice blister in a refrozen melt river on the Koettlitz Glacier Ice Tongue. The photo was taken from the top of a half-ineter-high linear ice mound along which the crack in the foreground runs.

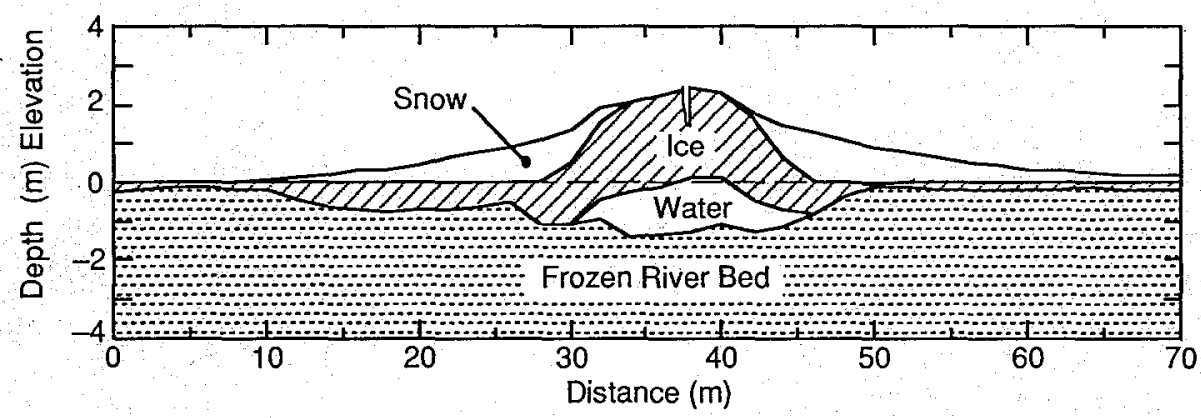

Figure 9. Cross section of a sinuous ice blister on the Katakluruk River near its discharge into Camden Bay, Beaufort Sea coast, Alaska. The in-situ water salinity and conductivity were $0.6 \%$ and $0.04 \mathrm{~S} / \mathrm{m}$, respectively.

the Koettlitz Glacier Ice Tongue nor on the ice field above the Jakobshavn Isbrae ice field.

\section{Alaskan ice blisters \\ Ice blisters also occur on rivers where the bed is impermeable or freezes to become impervious, such as in permafrost areas (Fig. 9). Many Russian and North American papers describe such features (Leffingwell 1919, Smith and Mertie 1930, Muller 1947, Carey 1970, 1973, Chacho et al. 1991, Crory 1991). On the North Slope of Alaska these river formations are numerous and conspicuous fea- tures easily seen from the ground or air.}

Between 1978 and 1984 I made helicopter reconnaissance flights along the Chukchi and Beaufort sea coasts of Alaska each spring. During these years, conical, long and sinuous, or odd-shaped ice blisters (Fig. 10) were seen on most of the frozen rivers near the sea coast. No river on the Alaska North Slope flows to the sea during the late winter period, but massive spring-fed icings ("tarins") do occur. Some icings reach the sea, and a few-for example, on the Firth River in the Yukon Territory and the Kongakut River on the North Slope of Alaska-grow so thick that they can survive one or more melt seasons (Fig. 11) (see also, summer and 


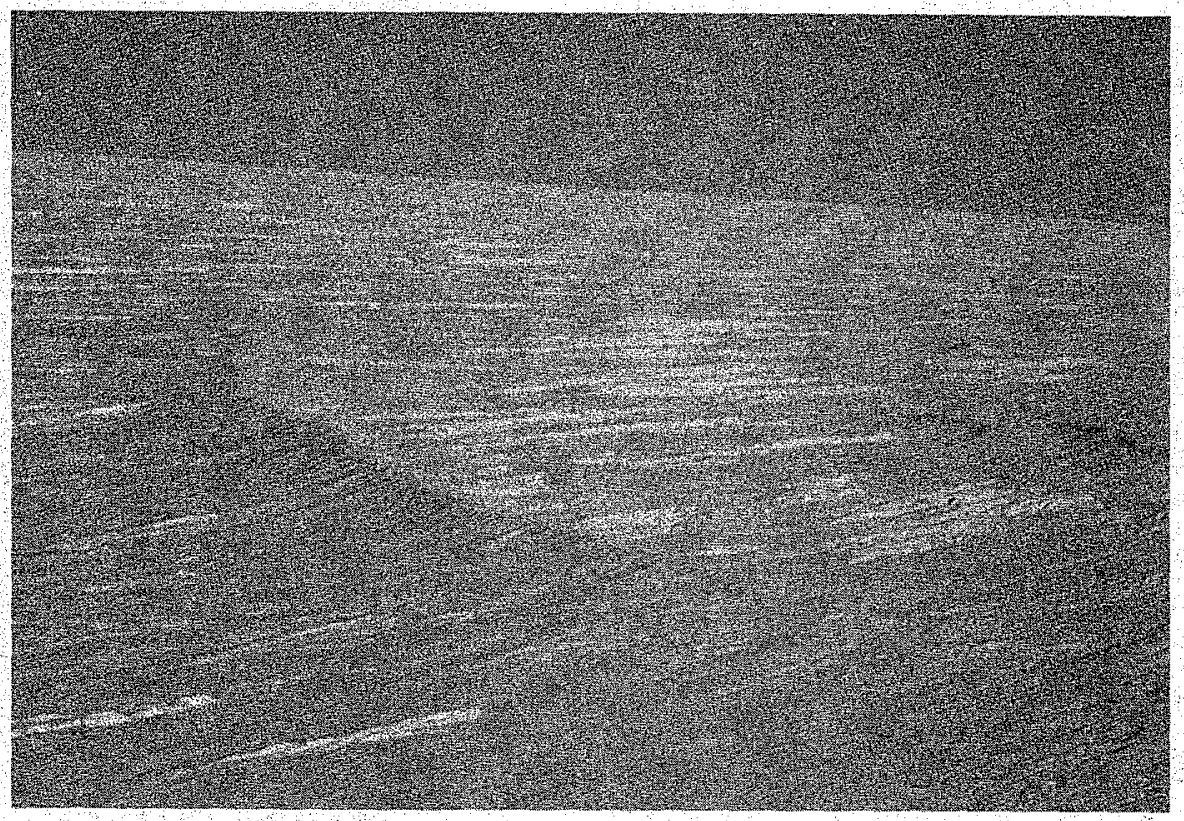

a. Long sinuous and small conical (far upper right) ice blisters.

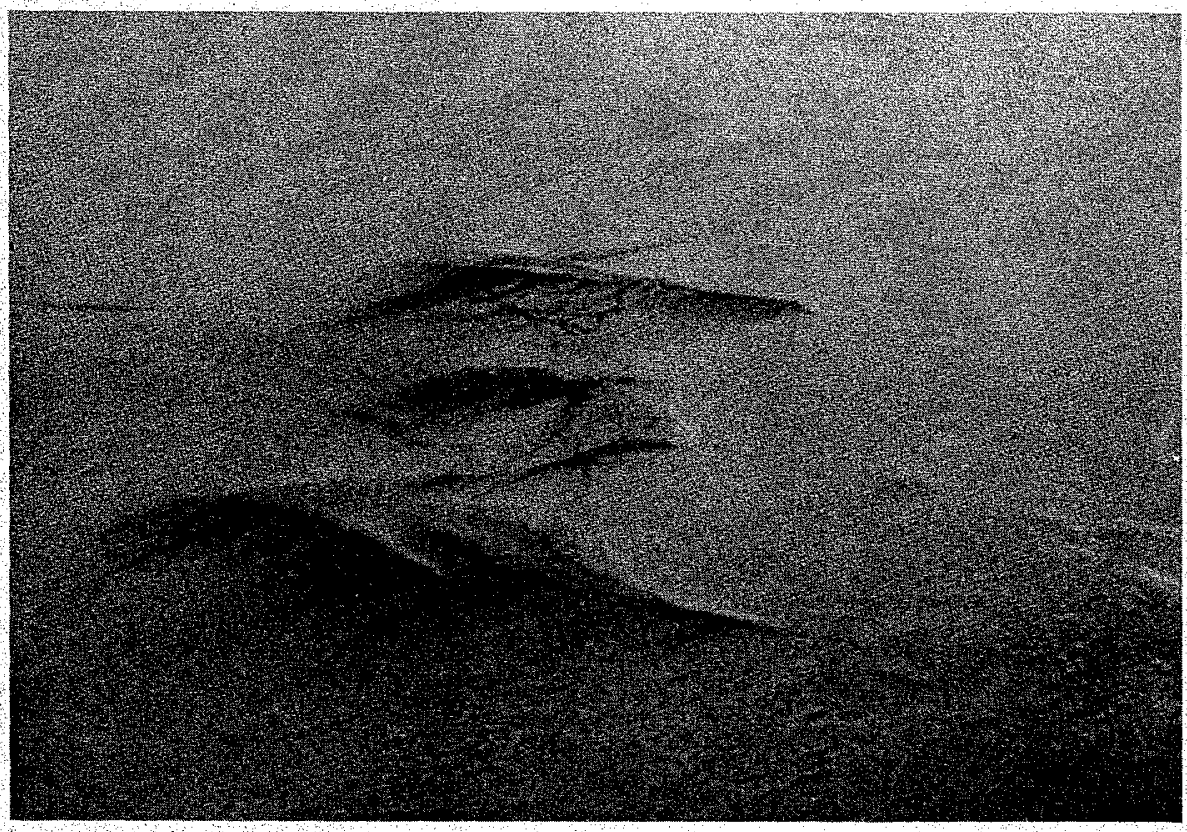

b. Oblong (top) and odd-shaped ice blisters.

Figure 10. Alaska North Slope river ice blister shapes.

fall 1973 Landsat imagery of the Alaska-Yukon Territory area [Kovacs 1976 and Fig. 20 in Crory. 1991]). We drilled through the apexes of a number of these river ice blisters. Many contained a core of water (Fig. 9). Similar to an observation of Are (1969), who drilled an ice blister surrounded by an icing, the water in the ice blisters we drilled would rise in the bore hole, thus relieving the confining pressure. At only one location did a very small quantity (less than a liter) of the water flow out at the top of the blister. The pressure of the confined water is not known, but it probably was much 


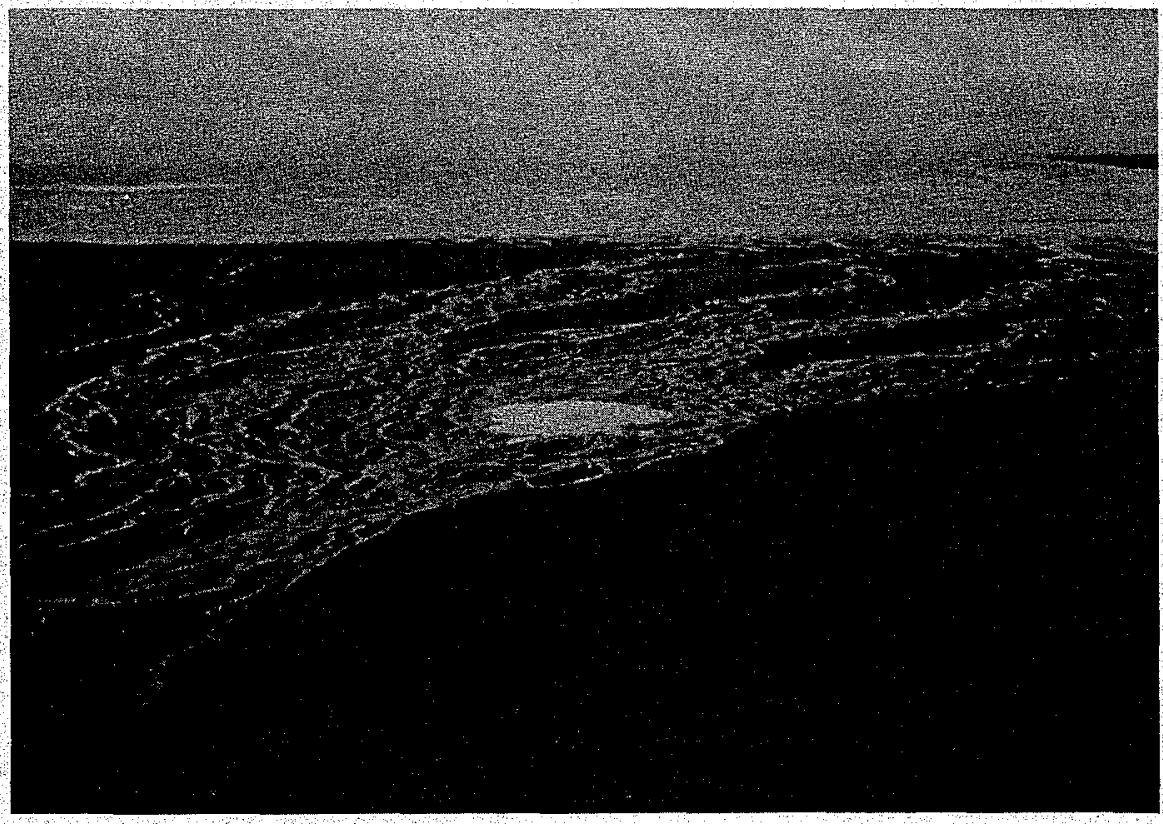

Figure 11. Icing remnant on the Firth River, Yukon Territory, Canada, in midSeptember 1981. The western tip of Herschel Island is at the top far right. A skim of sea ice had already formed on the ocean at this time.

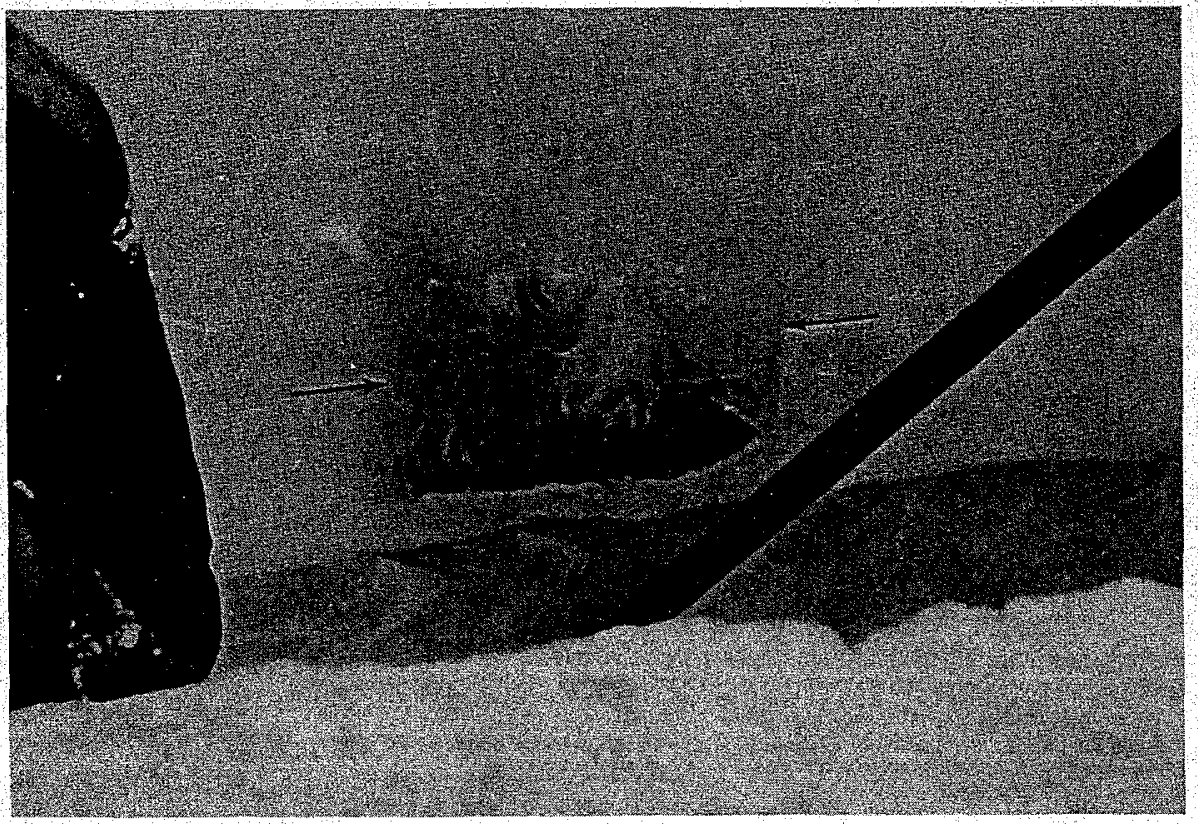

Figure 12. Trench cut into an ice blister alongside a cavity containing a boulder and some fibrous organic material. The ice wall of the cavity was ruptured by the ice chisel, and the meltwater from the cavity had drained onto the floor of the trench. The arrows define the cavity width. 
lower than the 5 MPa estimated by Petrov (1930) for the confined ground water below a seasonal frost mound. Pressures on the order of 25-100 KPa seem more realistic based on estimates of the hydraulic potential needed to lift the ice mass and on direct measurements of the water pressure in frost mounds by Pollard and French (1984). Observations of the water levels in the drill holes indicated that the blisters were not spring-fed and that the ice uplift is analogous to cream being forced upward from a freezing bottle of milk, or to the crown that often forms on the top or bottom of a frozen bucket of water. None of the ice blisters appeared to have ruptured, since no icings were observed at their bases.

In several of the ice blisters on the Katakturuk and Tamayariak rivers in Alaska, pebbles, boulders and organic debris were observed within the domed ice. Using a chain saw and ice chisel, we excavated a $1-\mathrm{m}$-deep trench in one ice blister, beside a debris inclusion (Fig. 12). The inclusion was found to contain fibrous organic material and a boulder approximately $0.2 \mathrm{~m}$ long and $0.07 \mathrm{~m}$ in diameter. When the face of the cavity was broken into, water flowed into the excavation. It was then found that the boulder rested inside a 0.25 -m-high water-filled cavity somewhat larger in width than the boulder. The boulder had apparently migrated downward about $0.25 \mathrm{~m}$ from its original position within the ice mass. The cavity water was found to have a salinity of $0.1 \%$. The water-filled cavity was formed by the penetration of solar radiation into the ice. The subsequent heat gained by the debris caused melting of the surrounding ice, and this in turn allowed for the downward migration of the boulder. Many ice-covered but water-filled cryoconite cavities, as found on glaciers, form in the same manner.

Similar debris inclusions were observed by Smith and Mertie (1930) in the ice mounds they investigated in 1924 on the Killick River in northern Alaska. They suggested that the pebbles and boulders, up to $0.2 \mathrm{~m}$ in diameter, were picked up from the river bottom. In this process the ice sheet would freeze downward and adhere to material resting on river bottom high points. Crystallization forces in the confined water body would lift the ice sheet and the debris frozen to the ice bottom. Continued ice growth would then entomb the debris. This process was apparently repeated frequently at their study area, as they reported seeing gravel debris embedded at various elevations within the ice.

Seasonal frost blisters tend "to shift location and to vary in size and shape from one year to the next" (Pollard 1988). This is equally true for ice blisters, which may develop along the same stretch of a river but often at new scour pool sites that formed during the previous spring run-off period. Crory (1991) showed a 3-m-high ice blister that developed in a drainage area beside the runway at Umiat, Alaska (Fig. 13), but also stated that such ice formations "do not necessarily form in the same location each year."

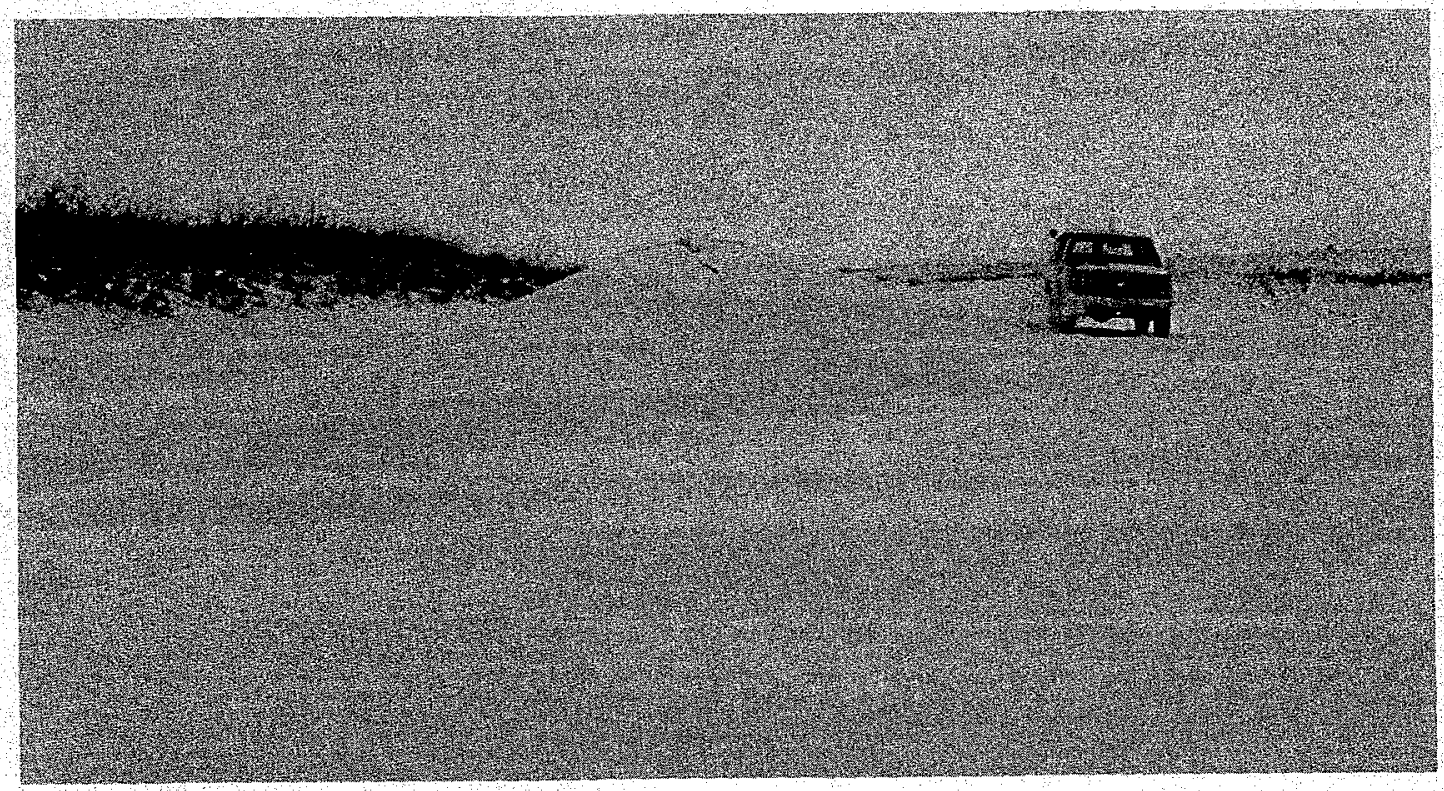

Figure 13. Three-meter-high ice blister in the drainage area beside the runway at Umiat, Alaska (Crory 1991). (Photo courtesy of F. Crory.) 


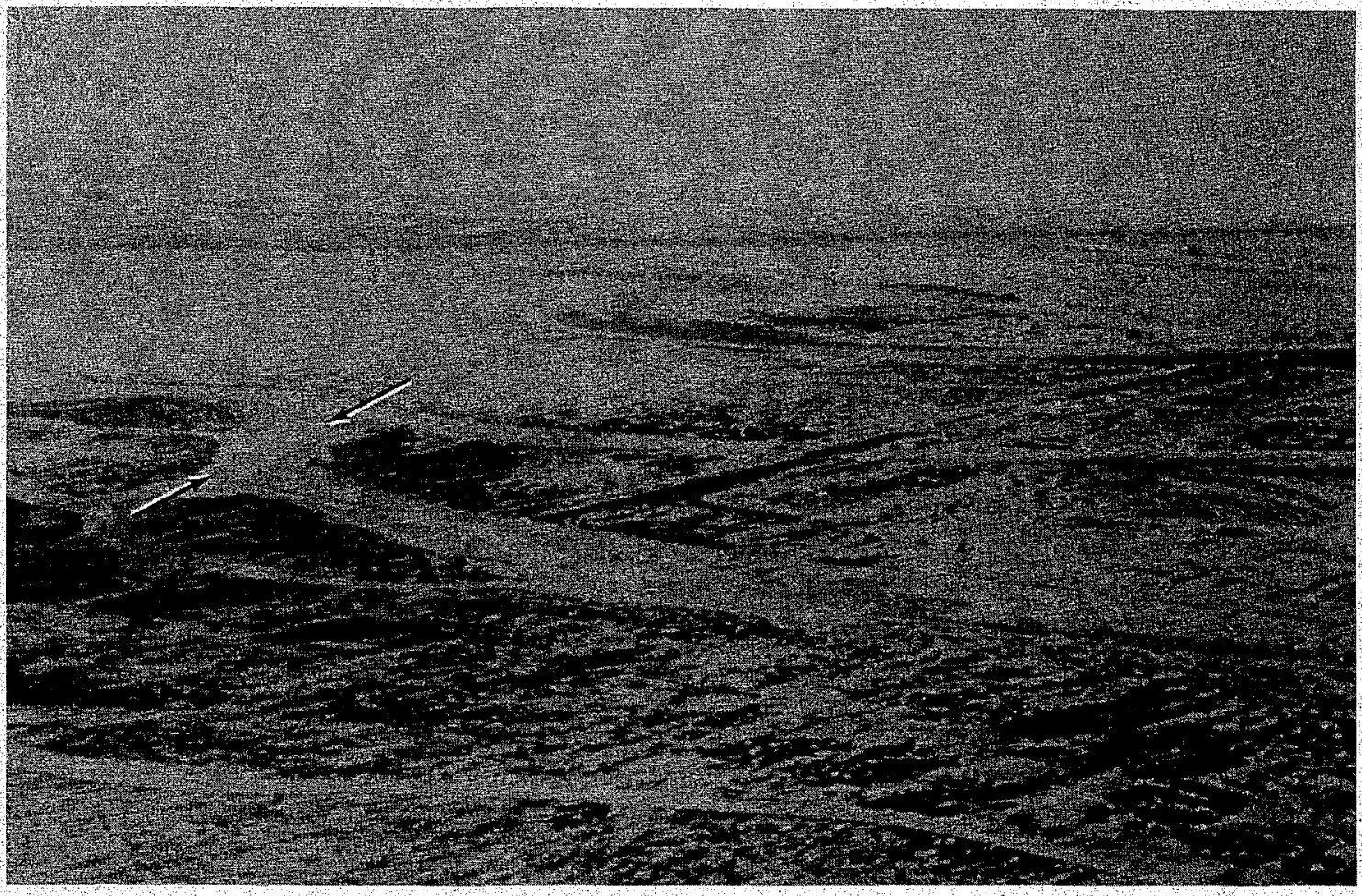

Figure 14. Ice blister $2.5 \mathrm{~m}$ high on a Kuparuk River channel. The ice blister length is defined by the arrows. An abandoned runway is situated to the right of the ice blister.

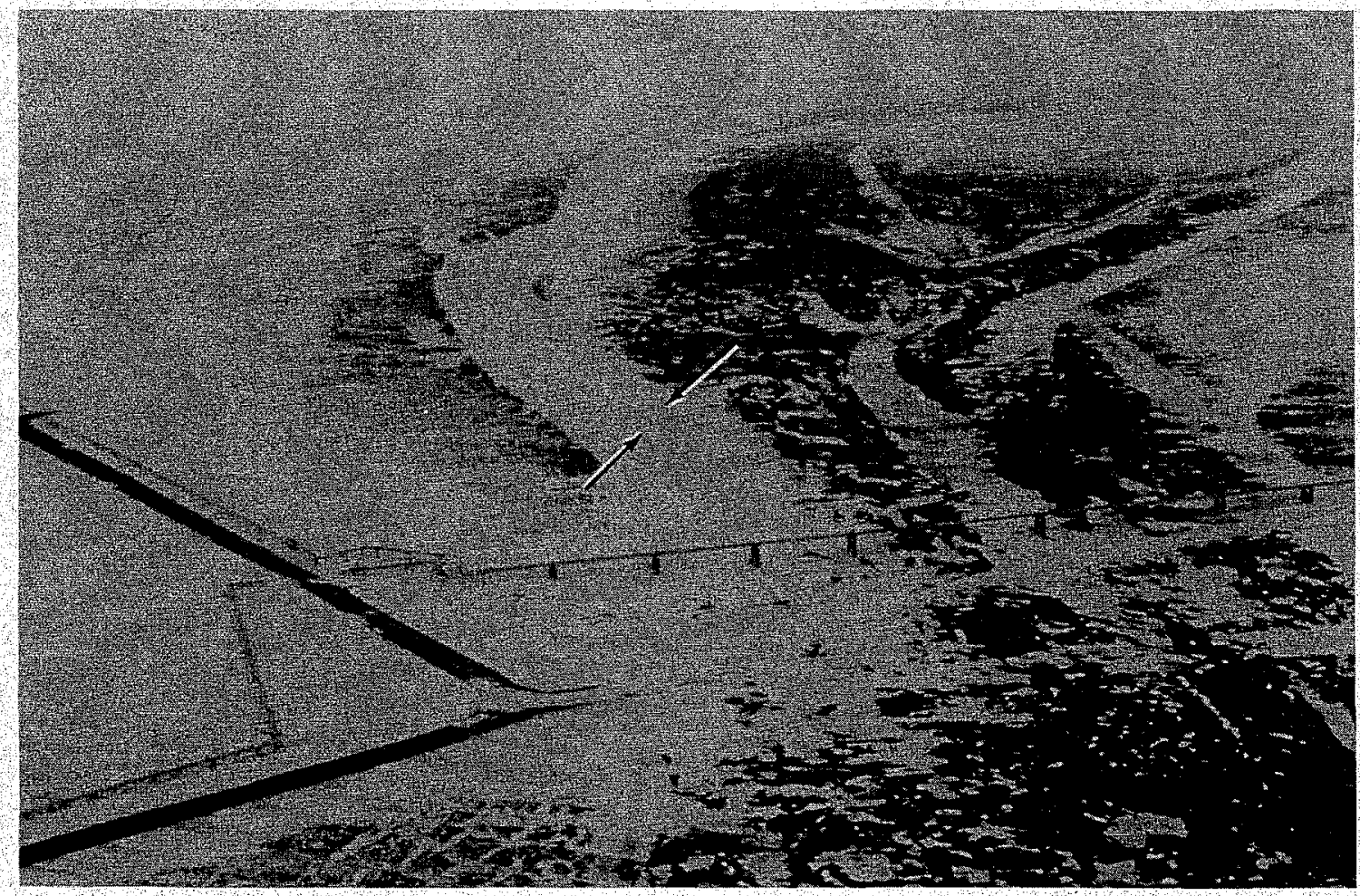

Figure 15. Ice blister (between arrows) in a Kuparuk River channel. The thin "linear" feature is an elevated oil pipeline. 
While river ice blisters are easily visible from a low-flying aircraft, it is of interest to know if they could be detected from a high-flying remote sensing aircraft In May 1990 I was involved in a joint U.S-Canadian remote sensing experiment near Prudhoe Bay, Alaska. A Convair 580 remote sensing aircraft of the Canadian Center for Remote Sensing was used to collect $C$-band-frequency synthetic aperture radar (SAR) imagery and other sensor data.

Ice blisters are common along the Kuparuk River, which is located west of Prudhoe Bay. One ice blister visited in May 1990 was near an abandoned runway (Fig. 14), and a second was near a pipeline crossing (Fig. 15). Drilling at the top of the $2.5-\mathrm{m}$ high ice mound shown in Figure 14 revealed ice about $1.5 \mathrm{~m}$ thick with an undetermined depth of water in it. The $1.5-\mathrm{m}$-high ice blister shown in Figure 15 was not drilled.

A C-band SAR image, obtained with a vertically polarized antenna, showing a portion of the
Kuparuk River is presented in Figure 16. The lower sloping arrow (labeled A) in Figure 16 points to a dark streak, which corresponds to the location of the ice blister shown in Figure 14. Above this arrow is a linear feature, which is the abandoned runway, also visible in Figure 14. The top sloping arrow (labeled B) in Figure 16 points to a very small dark spot, which is believed to be the ice blister shown in Figure 15. Dark areas in the SAR image represent highly reflective smooth areas. Such areas include the tundra lakes, many of which had either completely or partially snow-free smooth surfaces. As can be seen in Figure 16, there are numerous other dark areas in the meandering Kuparuk River channels. Three such areas are denoted by the three upward-pointing vertical arrows. These sites were visited and found to be not ice blisters but windpolished, snow-free ice areas. It can be concluded that while vertical polarized C-band SAR imagery may suggest sites where river ice blisters exist,

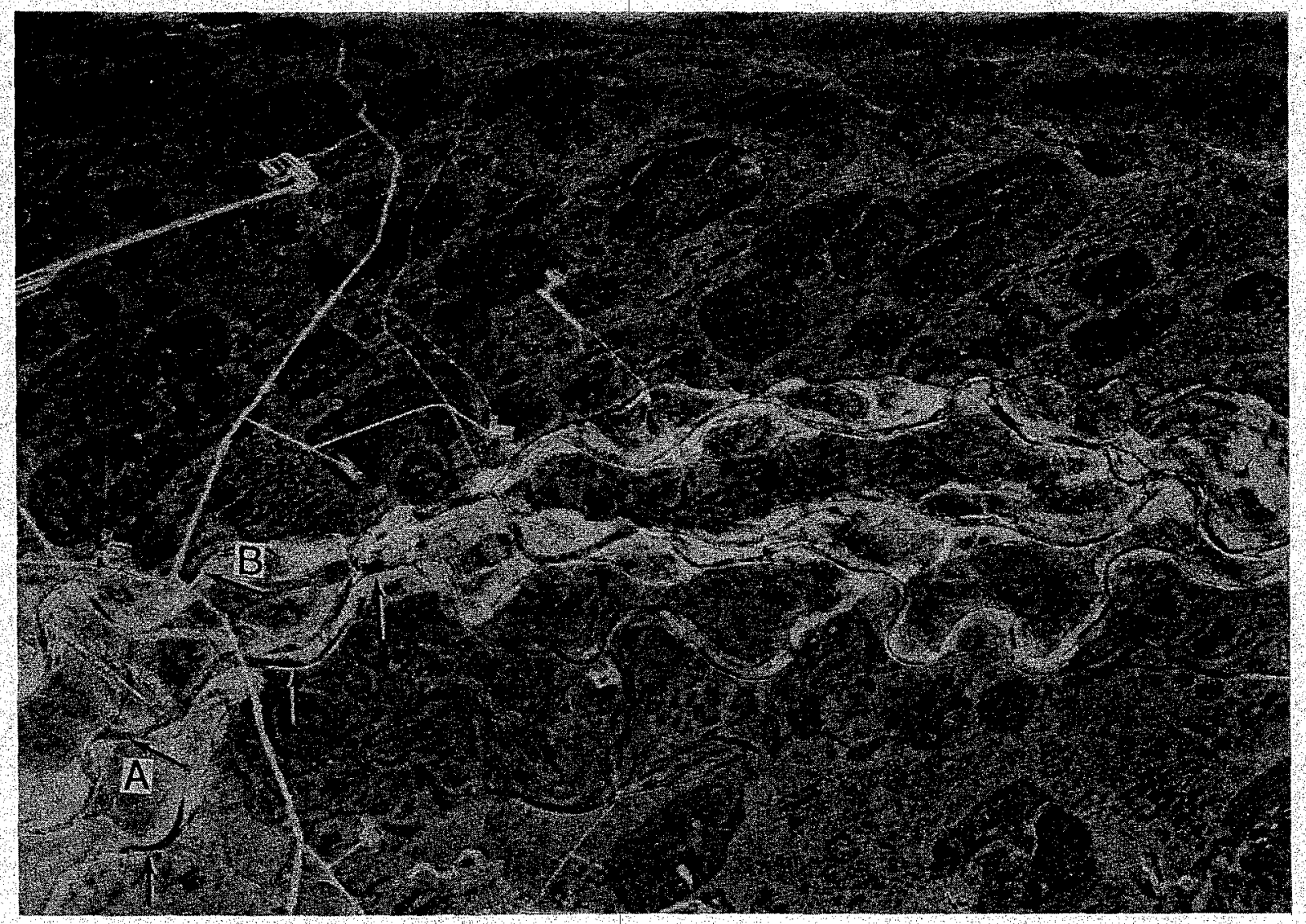

Figure 16. Canadian Center for Remote Sensing C-band SAR image taken from an altitude of about $6.1 \mathrm{~km}$, showing a section of the Kuparuk River system and some of the surrounding oil field development. The sloping arrows point to ice blisters. The vertical arrows point to some of the snow-free river ice areas. (Image courtesy of T. Lukowski, Canadian Center for Remote Sensing) 


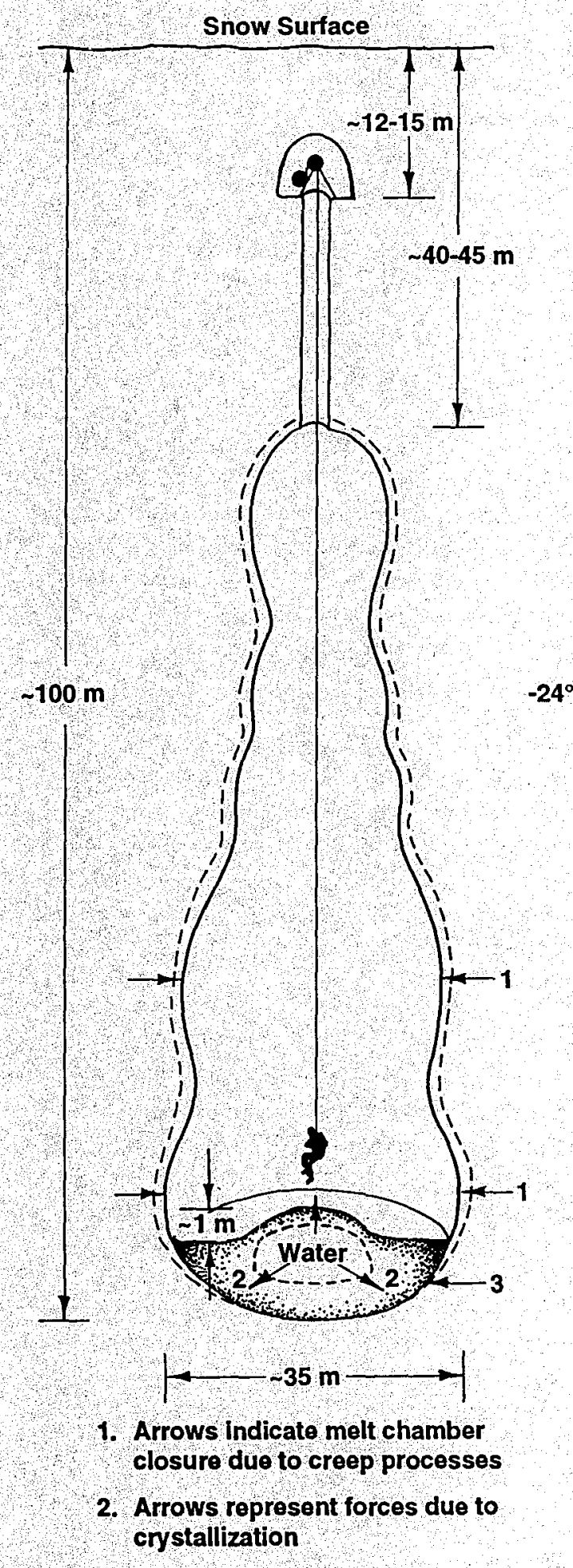

3. Refrozen well water

Figure 17. Cross section of an ice well at Camp Century, Greenland. numerous other areas produce a similar backscatter. Perhaps another SAR frequency band or another antenna polarization would offer better ice blister detection. Theoretical backscatter considerations for SAR appear to suggest otherwise.

\section{Greenland ice blisters}

River icings and ice blisters have been observed on the rivers of the Nunatarssuak area, east of Thule, Greenland (Colton and Holmes 1954). One ice mound was about $1.5 \mathrm{~m}$ high, $4.5 \mathrm{~m}$ wideand 7.5 $m$ long and was cracked parallel to the long, axis, similar to the one shown in Figure 8.

At Camp Century, Greenland, water was produced from an ice (Rodriguez) well. Steam or hot water was used to melt a hole into the ice cap to a depth of about $45 \mathrm{~m}$, where the $-24^{\circ} \mathrm{C}$ firn became "impermeable." Here the melt formed a large pool of water, which was withdrawn as needed by pumping.

In 1966 I was lowered on a "bosun's chair" into the second water supply well at Camp Century after it had been abandoned for about one year. Figure 17 shows the general shape of this well. The ice cover on the former pool of water was found to be domed, forming an ice blister about $1 \mathrm{~m}$ high, as depicted in Figure 17. The domed surface was cracked into pie-shaped wedges not unlike those of the Koettlitz Glacier Ice Tongue ice blister shown in Figure 5.

A similar ice blister was also observed in the first water well at Camp Century (Schmitt and Rodriguez 1963). When this well was abandoned, the water was about $5.3 \mathrm{~m}$ deep. Ten months later, when the top of the ice blister was drilled through, $1.7 \mathrm{~m}$ of ice was found above about $3 \mathrm{~m}$ of water. More ice formed on the surface of the pool than on the bottom: 1.7 vs about $0.6 \mathrm{~m}$. Schmitt and Rodriguez (1963) stated that "this is significant in empirically revealing the insulating properties of ice," which has a poor thermal conductivity. They also pointed out, as a result of their observations, that water may be stored for some time in a subglacial pool. Clearly the size of the pool, the initial volume of water therein, and the surrounding ice thermal conditions will govern the quantity of water available with time. In any event the ice blisters observed in the ice wells at Camp Century return us once again to the analogy of the appearance of an ice blister formation on the surface of a freezing bucket of water. 


\section{DISCUSSION}

Thesolid glaciâl ice blisters Echelmeyer etal. (1991) saw in Greenland and I observed in Antarctica probably grew following the general theory described by Sumgin (1941), LiverovskiiandMorozov (1941), Lewis (1962), Nekrasov (1969) and others as applying to frost mounds in general and river ice blisters, domes or mounds in particular. Once the runoff season ended and the shallower surface waters froze to the surrounding glacial ice, water in the deeper pools becamefully confined by ice. With time the expansive forces in the confined water, associated with continued freezing, either gradually, intermittently or suddenly forced the ice cover upward (van Everdingen [1982] measured a frost blister growth of $0.55 \mathrm{~m}$ in one day). During this process the ice blisters cracked at their apexes, and secondary cracks formed until all the water in the blisters had frozen and expansive uplift stopped. Since no icings existed beside the Koettlitz Glacier or Alaska river ice blisters visited, none of the confined water had escaped during ice upliftand fracturing. The hollow iceblisters observed on theJakobshavn Isbraeice field by Echelmeyer etal. (1991) had apparently drained. The general ice blister formation process described above is also applicable to the ice mounds observed on many Alaskan rivers, as well as to those that developed in the subsurface glacial well pools at Camp Century.

The question may be asked: Why are ice blisters of interest? An abundant supply of water for domestic and fire-fighting purposes is of critical importance at any cold regions site (Cederstrom et al. 1953, Alter 1969). This is a problem on the North Slope of Alaska, wheremost fresh water bodies areshallow and freeze completely during the winter. Ice blister sites may, therefore, offer an expedient but limited source of potable water. However, our limited drill hole measurements, and the more extensive ones made by Chacho et al. (1991) on several Alaska North Slope rivers, revealed that not all ice blisters form over pools of water deep enough to preclude complete winter freeze-up. Indications are that, for some Alaskan rivers, ice blisters over about $1.4 \mathrm{~m}$ high have a high probability of containing water (Chacho et al. 1991).

\section{LITERATURE CITED}

Alter, A.J. (1969) Water supply in cold regions. USA Cold Regions Research and Engineering Laboratory, Monograph III-C5a.
Are, F.Z. (1969) Mechanism of development and degradation of naleds in Ulakan-Taryn Springs. In: Siberian Naleds (O.N. Tolstikhin and V.M.Piguzova, Eds.), p. 107-116. USA Cold Regions Research and Engineering Laboratory, Draft Translation 399 (unpublished).

Bogomolov, N.S. and A.N. Sklyarevskaya (1969) On exploration of hydrolaccoliths in the southern part of Chilinskaya Oblast. In Siberian Naleds (ON. Tolstikhin and V.M. Piguzova, Eds.), p. 187-191. USA Cold Regions Research and Engineering Laboratory, Draft Translation 399 (unpublished).

Cailleux, A. (1962) Ice mounds on frozen lakes in McMurdo Sound, Antarctica. Journal of Glaciology, 4(31): 131-133.

Carey, K.L. (1970) Icing occurrence, control and prevention: An annotated bibliography. USA Cold Regions Research and Engineering Laboratory, Special Report 151.

Carey, K.L. (1973) Icings developed from surface water and ground water. USA Cold Regions Research and Engineering Laboratory, Monograph III-D3.

Cederstrom, D.J., P.M. Johnston and S. Zublitsky (1953) Occurrence and development of ground water in permafrost regions. U.S. Geological Survey, Circular 275.

Chacho, E.F., Jr, C.M. Collins, A.J. Delaney and S.A. Arcone (1991) River icing mounds: A winter water source on the eastern North Slope of Alaska. In: Northern Hydrology: Selected Papers, Proceedings of the Northern Hydrology Symposium, Saskatoon, Saskatchewan, Canada, (T.D. Powers and C.S.L. Ommanney, Ed.), p. 32-45.

Colton, R.B. and C.D. Holmes (1954) Geomorphology of the Nunatarssuak area. Final Report on the Scientific Program (Program B), Operation Ice Cap 1953. Stanford Research Institute.

Crory, F.E. (1991) Construction guidelines for oil and gas exploration in northern Alaska. USA Cold Regions Research and Engineering Laboratory, CRREL Report 91-21.

Echelmeyer, K., T.S. Clarke and W.D. Harrison (1991) Surficial glaciology of Jakobshavns Isbrae, West Greenland:Part I. Surface morphology. Journal of Glaciology, 37(127): 368-382.

Frederking, R.M.W. (1979) Rupture of an ice mound near Cape Dorset, N.W.T. Canadian Geotechnical Journal, 16: 604-609.

Kovacs, A. (1976). Grounded ice in the fast ice zone along the Beaufort Sea coast of Alaska. USA Cold Regions Research and Engineering Laboratory, CRREL Report 79-31. 
Leffingwell, E. DeK. (1919) The Canning River region, northern Alaska. U.S Geological Survey, Professional Paper 109.

Lewis, C.R (1962) Icing mound on Sadlerochit River, Alaska. Arctic, 15(2): 145-150.

Liestol, O. (1977) Pingos, springs, and permafrost in Spitsbergen. ARBOK 1975, Norsk Polarinstitutt, Oslo, Norway, p. 7-29.

Liverovskii, A.V. and K.D. Morozov (1941) Construction on permafrost. USA Corps of Engineers Frost Effects Laboratory, ACFEL Report TL-21.

Muller, S.W. (1947) Permafrost or Permanently Frozen Ground and Related Engineering Problems. Ann Arbor, Michigan. J.W. Edwards, Inc.

Nekrasov, I.A. (1969) On ground interbedding in ice hummocks of naleds. In: Siberian Naleds (O.N. Tolstikhin and V.M. Piguzova, Ed.), p. 192-196. USA Cold Regions Research and EngineeringLaboratory, Draft Translation 399 (unpublished).

Paige, R.A. (1968) Sub-surface melt pools in the McMurdo Ice Shelf, Antarctica. Journal of Glaciology, 7(51): 511-516.

Petrov, V.G. (1930) The naleds of the Amur-Yakutsk highway. Izdanie Akademi NaukSSSR i NauchnoIssledovatel'skogo Avtomobil'no. Dorozhanogo Instituta.

Plashchev, A.V. (1956) Rupture of an ice mound. Priroda, 45: 9-113.

Pollard, W.H. (1988) Seasonal frost mounds. In: Advances in Periglacial Geomorphology (MJ. Clark, Ed.), P. 201-229. New York: John Wiley and Sons, Ltd.

Pollard, W.H. (1991) Seasonal frost mounds. The Canadian Geographer, 35(2): 214-218.
Pollard, W.H. and H.W.French (1984) The groundwater hydraulics of a seasonal frost mound, North Fork Pass, Yukon Territory. Canadian Journal of Earth Sciences, 21(10): 1073-1081

Pollard, W.H. and H.W. French (1985) The internal structure of ice crystallography of seasonal frost mounds. Journal of Glaciology, 3(108): 157-162.

Schmitt, R.P. and R. Rodriguez (1963) Glacier water supply and sewage disposal systems. Symposium on Antarctic Logistics, Boulder, Colorado, National Academy of Sciences, National Research Council, p. 329-338.

Sloan, C.E., C. Zenone and L.R. Mayo (1976) Icings along the Trans-Alaska Pipeline route. U.S. Geological Survey, Professional Paper 979.

Smith, P.S. and J.B. Mertie, Jr. (1930) Geology and mineral resources of northwestern Alaska. US. Geological Survey, Bulletin 815.

Strugov, A.S. (1955) Rupture of a hydrolaccolith. Priroda, 46(6): 117.

Sumgin, M.I. (1941) Icings and icing mounds. Priroda, 30(1): 26-33.

Van Autenboer, T. (1962) Ice mounds and melt phenomena in the Sor-Rondaine, Antarctica. Journal of Glaciology, 4: 349-354.

van Everdingen, R.O. (1978) Frost mounds at Bear Rock, near FortNorman, Northwest Territories, 19751976. Canadian Journal of Earth Sciences, 15: 263-276.

van Everdingen, R.O. (1982) Frost blisters of the Bear Rock Spring area near Fort Norman, N.W.T. Arctic, 35(2): 243-265.

Wright, C.S. and R.E. Priestley (1922). Glaciology, British (Terra Nova) Antarctic Expedition 1910-1913. London: Harrison and Sons, Ltd. 
Public reporting burden tor this collection of information is estimated to average t hour per response, including the time for reviewing instructions, searching existing data sources, gathering and maintaining the data needed, and completing and reviewing the collection of information. Send comments regarding this burden estimate or any other aspect of this collection of information, including suggestion tor reducing this burden to Washington Headquarters Services, Directorate for Information Operations and Reports, 1215 Jefferson Davis Highway, Suite 1204 , Arlington. VA22202-4302, and to the Office of Management and Budget, Paperwork Reduction Project (0704-0188), Washington, DC 20503 .

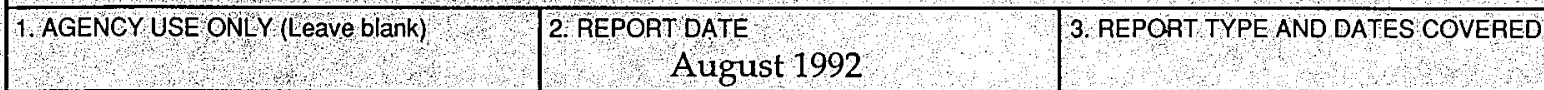

4. TITLE AND SUBTITTEE

5. FUNDING NUMBERS

Glacier, River and Sea Ice Blister Observations

6. AUTHORS

Austin Kovacs

7. PERFORMING ORGANIZATION NAME(S) AND ADORESS(ES)

U:S. Army Cold Regions Research and Engineering Laboratory

72 Lyme Road

Hanover, New Hampshire 03755-1290

8. PERFORMING ORGANIZATION

REPORT NUMBER

Special Report $92-22$

9. SPONSORING/MONITORING AGENCY NAME(S) AND ADDRESS(ES)

10. SPONSORINGMONITORING AGENCY REPORT NUMBER

11. SUPPLEMENTARY NOTES

12a DISTRIBUTION/AVALLABILITY STATEMENT

12b. DISTRIBUTION CODE

Approved for public release, distribution is unlimited.

Available from NTIS, Springfield, Virginia 22161

\section{ABSTRACT (Maximum 200 words)}

Ice blister observations made by the author in Greenland, Alaska and Antarctica are discussed. Ice blisters up to $3 \mathrm{~m}$ high and tens of meters long were observed on rivers and glaciers as well as on a subsurface glacial pool. Ice blisters observed by other investigators are also discussed, as is ice blister morphology (solid, hollow or waterfilled), the processes associated with their formation and their potential as a resource for potable water.

\begin{tabular}{|c|c|c|}
\hline $\begin{array}{l}\text { Freshwater ice } \\
\text { Glacier ice }\end{array}$ & $\begin{array}{l}\text { Ice blisters } \\
\text { Ice mounds }\end{array}$ & $\begin{array}{l}\text { River ice } \\
\text { Water supply }\end{array}$ \\
\hline $\begin{array}{l}\text { 17. SECURTY CLASSIFICATION } \\
\text { OF REPORT }\end{array}$ & $\begin{array}{l}\text { 18. SECUBITY GLASSIFICATION } \\
\text { OF THIS PAGE }\end{array}$ & $\begin{array}{l}\text { 19. SECURITY CLASSIFICATION } \\
\text { OF ABSTAACT }\end{array}$ \\
\hline UNCLASSIFIED & UNCLASSIFIED & UNCLASSIFIED \\
\hline
\end{tabular}

15. NUMBER OF PAGES

16. PRICE CODE

20. LIMITATION OF ABSTRACT

$\mathrm{UL}$

Standard Form 298 (Rev. 2-89) Prescribed by ANSI Std. Z39-18
$298-102$ 298.102 